\title{
EXTENSION OF PARENT COMPANY SHAREHOLDERS' RIGHTS TO PARTICIPATE IN THE GOVERNANCE OF SUBSIDIARIES
}

\author{
Richard M. Buxbaum*
}

Rarely does a common law decision from outside the American orbit provide an opportunity for developing American corporation law doctrine, and more rarely still does a civil law system case harbor this potential. Yet a recent decision of the German Supreme Court, In re J. F. Muller \& Sohn $A G,^{1}$ itself indirectly but clearly influenced by American principles, affords an unusual comparative opportunity to clarify American doctrine in some important particulars. The case not only extends German doctrine beyond its primarily statutory framework because of clear inadequacies of coverage found by the German Supreme Coureme Court to exist in that statutory system, but also breaks new ground in developing a shareholder's remedy that may be a first step towards a "common law" derivative suit. Most significantly, however, it contributes to the appropriate placement of affliated enterprise systems within corporation law rules originally tailored to the context of single, unaffiliated entities, and in doing so offers the opportunity constructively to rethink American doctrine in that field.

Maller concerns the complaint of a substantial minority shareholders against the decision of the Board of Directors to spin off not the principal but a major-and the only profitable-asset of the company to a separate, originally wholly-owned entity. The parent company, active in the forest products sector, also owned a maritime dock and warehouse. It first recommended its shareholders to amend the corporate articles in rather general terms to permit the formation of, acquisition of and participation in other entities, as well as to permit the transfer of all or part of its assets to such entities. Its management did explain this request, at the shareholders' meeting, by specific reference to the desirability of separating its port facility and establishing it in a different but wholly owned forms. In this relatively abstract enabling amendment the complainant concurred. The later actual transfer, however, was to a separate limited partnership, of which a newly-incorporated close corporation, itself the wholly-owned subsidiary of the original company, be-

- Professor, of Law, University of California, Berkeley. By all rights Professor Dr. Bernhard Grossfeld, Munster, should be listed as co-author. Even his heroic efforts, however, undoubtedly have failed to remove all my errors let alone the ones caused by my intransigence. Better, therefore, that he share no complicity beyond what is already inherent in my thanks.

1. Decision of BGH, 25, Feb. 1982, repr. in 37 Juristenzeitung [JZ] 602 (1982). 
came both the general partner and-with two strawmen-the sole limited partner.

The complainant objected to this particular form of the transaction in part because the transferred business was the profit center of the corporation. His main objection, however, was that this form of transfer opened the door to a major transformation of the basic enterprise by means of an increase in the capitalization of the newly spun-off entity without honoring the preemptive right of the parent's shareholders, a right that would exist were such a capital increase to be achieved by the issuance of additional shares directly by the original corporation. The (nominal) defendant, the parent corporation, argued that the transfer had independent economic and organizational justification, but in addition argued that the complainant had no standing to sue because that was a usurpation of managerial functions.

The major prayer for relief-a declaratory judgment that the transactions achieving the spinoff were invalid-had both procedural and substantive aspects. The first substantive ground for the transaction's alleged invalidity, that it required specific shareholder approval which the earlier charter amendment approval did not supply, presented the factually debatable but doctrinally straightforward question whether, in American terms, this was the equivalent of a sale of all or substantially all assets. ${ }^{2}$

Doctrinally problematical in a procedural sense was that the statute expressly provides for relief, at the instance of individual dissenting shareholders, only against allegedly void or voidable shareholder decisions but not for complaints against decisions not presented to shareholders. ${ }^{3}$ The court's recourse to general principles of the Code of Civil Procedure to supplement the specific procedures of the Corporations Code (when to do so would not violate a statutory intention not to provide that relief) follows a recent line of decisions and requires no further analysis here. ${ }^{4}$

Equally important but equally unsurprising was the refusal of the court to consider the problem of relief solely within the context

2. See, e.g., Model Business Corporation Act $\S 79$.

3. Aktiengesetz [AktG] $\$ 243$ (English translation in Muller \& Galbraith, eds., The German Stock Corporation Law (1966)); for a brief English language discussion of these procedures, see Grossfeld, "Management and Control of Marketable Share Companies," XIII Int'l. Encycl. Comp. L. ch. 4 ("Business and Private Organizations") 108; von Falkenhausen \& Steefel, "Shareholders' Rights in German Corporations," $10 \mathrm{Am}$. J. Comp. L. 407, 429 (1961); Steefel \& von Falkenhausen, "The New German Stock Corporation Law," 52 Cornell L.Q. 518, 543 (1967).

On the narrow but related problem of combining positive declaratory relief (in the nature of what would be a statutory quo warranto declaration in American law) with a finding of invalidity of an action, and its recent resolution in German law, see Schmidt, "Geklarte und offene Probleme der positiven Beschlussfeststellungsklage," 25 Die Aktiengesellschaft [AG] 169 (1980).

4. Decision of BGH, 13 March, 1980 repr., i.a., in $25 A G 187$ (1980); see Rehbinder, "Zum konzernrechtlichen Schutz der Aktionare einer Obergesellschaft," 12 Zeitschrift fur das Gesellschafts- und Unternehmensrecht [ZGR] 92 (1983); Grossfeld \& Brondics, "Die Aktionarsklage-nun auch im deutschen Recht," 37 JZ 589 (1982). 
of these contending ownership interests. Particularly the possible return of the assets to the parent company, said the court, now needs to be considered in the light of possible intervening third party interests such as those of creditors of the meanwhile operational limited partnership.

It is in the procedural discussion of the right of a shareholder directly to demand relief from the corporation by equating the acts of its managing organs with the entity itself that the first of the comparatively interesting issues surfaces. The plaintiff had demanded that the corporation retransfer the assets from the subsidiary partnership to itself. This demand, apart from being time-barred, cut against the grain of German corporation law in two ways. First, the code insists on the primary jurisdiction of the supervisory council (Aufsichtsrat), rather than of shareholders, to protect the entity against usurping, self-dealing or imprudent actions of the executive board (Vorstand). ${ }^{5}$ Second, the code also favors the supremacy of majoritarian decisions at shareholders' meeting over any "minority rights" concept. It limits dissenters to a few structural complaints such as defects in enabling resolutions or other formal issues, and to a limited "abuse of right" attack on the merits of shareholders' direct or ratifying decisions. ${ }^{6}$ The specific notion propounded by the plaintiff, that shareholders could directly prevent management from usurping decisionmaking powers properly belonging to the shareholders, previously had foundered on the asserted lack of any direct legal relationship between Vorstand and shareholders, leading to the practically unsatisfiable requirement that a shareholder could not sue the Vorstand or its members to require that organ to present such a structural decision to the shareholders. ?

Here arises a first indirect but illuminating comparison with American law. This postulated absence of a direct shareholder-Vorstand relationship, while stated in procedural terms, substantively suggests that directors owe fiduciary duties of prudence and loyalty only to the entity they manage, not to its owners. ${ }^{8}$ Whereas this, in old, no longer respectable American doctrine had "only" substantive results, ${ }^{9}$ in the German law it also has the even more interesting

5. See Grossfeld supra n. 3 at $64-65,107$; von Falkenhausen $\&$ Steefel, supra n. 3 at 416 .

There is, however, substantial tension between this special shift of decisionmaking power and the generally rather limited right of the Aufsichtsrat to obtain even so much information from the Vorstand as is needed to exercise its control function-a limit based in part on the reality that today the Aufsichtsrat includes interests of labor as well as capital. To this issue, and to the role thereto of AktG $\S 90$, compare Lutter, Information und Vertraulichkeit in Aufsichtsrat (1979) with Mertens, "Zur Berichtspflicht des Vorstands gegenuber dem Aufsichtsrat," $25 A G 67$ (1980). (1980).

6. See authorities cited supra n. 3; Wiedemann, Gesellschaftsrecht 454 ff. 463

7. This problem is briefly described in Mertens, Kolner Kommentar zum Aktienrecht, Anno. preceding $\$ 76$, comment 6 (prov. ed. 1970).

8. See von Falkenhausen \& Steefel, supra n. 3 at 416.

9. See, e.g., the compilation and discussion in Jennings \& Buxbaum, Corporations-Cases and Materials 514 ff. (5th ed. 1979). 
and, because so totally preclusive of substantive doctrinal evolution, even more important procedural result of preventing suit by denying standing.

Using general associational principles claimed to precede and underlie specific Corporations Code provisions, the Muller opinion shortcuts this impassable detour by permitting a shareholder's action to be brought, nominally against the company, for relief against an illegitimately effected decision (possibly including even its rescission). It is important, of course, to note the limited reach of the opinion. The underlying claim is only that the challenged transaction was not within the power of the directors to effectuate, but require a decision of the shareholders. Only that area now is brought within the ambit of what American doctrine might characterize as a derivative suit, and even it-especially it-is subject to potential nullification by specific ratification of the transfer transaction, even retroactively, through a shareholders' vote. ${ }^{10}$

Nevertheless, with this innovative characterization of a suit against "unrelated" directors as one against the entity (with which the shareholder does have that necessary relation) the German law may also be backing into partial recognition of a derivative suit concept. ${ }^{11}$

A look at the remedy at issue in the Muller case may help explain this perhaps surprising inference, since at first glance the action seems to be a direct, rather than a derivative one. Transfer of the assets ostensibly damaged only the shareholders, by depriving them of continuing participation in decisions about the use of those assets-decisions which it would have been their right to take had the assets remained in their (transferor) company, but which now will be taken by Vorstand representatives wearing the hat of general partner in the transferee partnership. That, of course, is classically direct harm, not harm to the corporation. ${ }^{12}$ But a major reason for objecting to this change in the decisionmaking pattern is fear of imprudent or self-interested decision by the partnership. These hypothetical transactions could damage the assets directly, and thus diminish both the value of the parent's holdings and (in consequence) the asset value of the parent itself. These transactions also could be of a kind to benefit parent company insiders, ${ }^{13}$ to the detriment of the partnership (and thus, again, to the detriment of the parent company). Imprudent, reckless transactions by the

10. See Rehbinder, supra n. 4 at 102 ; Grossfeld \& Brondics, supra n. 4 at 590 . Furthermore, the reluctance of the court to envisage rescission and to grant instead parent company shareholder voting rights to analogous transactions planned by the illegitimately created subsidiary indeed may signal a doctrinal limit on the scope of any remedy; cf. Rehbinder, id. at 103.

11. Cf. Grossfleld \& Brondics, id.; but cf. Rehbinder, id. at 104-106.

12. See, e.g., Wiedemann, supra n. 6 at 458.

13. Either dominant shareholders or non-shareholding directors or officers; even in the first case the corporation, as an entity comprised of capital participation by all shareholders, is understood as being harmed. 
management of the partnership would exemplify the first type of loss-causing event; self-dealing ones the second type. The question then is whether Muller's use of "direct relationship" arguments, justifying the plaintiff's attack on the Vorstand transfer decision by calling it a suit against the company, which really is only a nominal defendant here, could be extended to cases involving damage to the entity as a result of imprudent or self-dealing loss-causing Vorstand business transactions.

At present any loss-causing transaction is challengeable only indirectly and under practically unrealistic conditions. A complaining shareholder can only enforce the company's right of recovery against Vorstand (or Aufsichtsrat) members if representing at least $10 \%$ of the issued stock. This restriction, imposed by $\S 147$ of the Corporations Code, may well apply to limit this newly invented concept of direct shareholder action to the extent it would include the remedy of damages. ${ }^{14}$

It remains to be seen, however, whether German doctrine will take the next step towards a type of derivative suit that seeks remedies other than damages-i.e., injunction and rescission cases-and if so, whether it will apply similar limiting conditions by analogy.15 The rhetorical argument is clear. If direct challenge to managerial decisions now is possible because of defects in the enabling procedure, the underlying similarity between defects based on lack of power and defects based on abuse of power will come to be stressed. The American experience with the characterization of self-dealing transactions, and particularly with the statutory and decisional tendency to move such decisions from the ordinarily competent but tained and therefore disabled (director) level to the next higher (shareholder) level, offers an especially telling analogy. ${ }^{16}$

It is, of course, only a partial analogy, but its limited value is due less to rhetorical or doctrinal differences between the two corporation law systems, nor even so much to general legal-cultural differences, as to specific corporate institutional differences-first among these being the two-tier management structure of the German Aktiengesellschaft. With the insertion of the supervisory council (Aufsichtsrat), comprised except for most of its labor members of outside directors, between executive board (Vorstand) and share-

14. For a fuller explanation of this barrier in the context of the Muller case itself, see the extensive discussion (of the lower court decision) in Timm, "Hauptversammlungskompetenzen und Aktionarsrechte in der Konzernspitze," 25 $A G$ 172, 185 (1980). For a general, brief review see Grossfeld, supra, n. 3 at 109f; for a concise explanation of the differences between this limited right and the better procedural position of the minority shareholder of a subsidiary in an affliated enterprise system to move against transactions of the parent (the Konzernklage of AktG $\$ \$ 309$ ff), see Rehbinder, "Gesellschaftsrechtliche Probleme mehrstufiger Unternehmensverbindugen," $6 Z G R$ 581, 599-601 (1977), with further citations.

15. Cf. Timm, supra n. 14 at 185 ; Grossfeld \& Bondics, supra n. 4 at 590 ; compare Rehbinder, supra n. 4 at 106.

16. Buxbaum \& Schneider, "Die Fortentwicklung der Aktionarsklage und der Konzernklage im amerikanischen Recht," 11 ZGR 199 (1982). 
holder body, the occasion for at least self-dealing complaints is significantly reduced. ${ }^{17}$ What remains is typically converted by this first-tier supervision into a duty of prudence issue, an issue less susceptible to the rhetorical lack of power/abuse of power analogy, and thus not in a posture that readily triggers judicial review. ${ }^{18}$ In any event, the court was explicit in basing its decision to allow this new cause of action on the narrowest possible ground, the shareholder's right to vote on the transaction, rather than on more general rights to test the fairness or prudence of the transaction once voted on.

This prediction is strengthened by recent German case law that created quite different substantive standards of flduciary duty (in the subset of loyalty) for the three-tiered Aktiengesellschaft, permitting its manager to shelter behind the shield of the corporation and denying-in typical corporate opportunity and sale of control cases-the existence of any fiduciary duty directly to shareholders in the first place, in contrast to the situation in the close corporation context. ${ }^{19}$

All in all, while as to these aspects the Muller case and its implications illuminate the American treatment of shareholders' complaints in interesting ways, their significance is rather to German doctrinal development as illuminated by American experience. It is when the case turns to the role of parent company shareholders in affliated enterprise systems that it becomes directly instructive to American corporation law.

The plaintiff further argued that as a remedy the corporate and individual defendants should pass through to parent company shareholders all decisions to be taken at the subsidiary limited partnership level to the extent that, within a single enterprise, they would be the subject of shareholder rather than management decisionmaking. Although the court rejected the argument in its generalized, absolute version, it recognized the reality that shareholder decisionmaking power could be evaded or dissipated in this situation, and accepted the pass-through concept for at least all substantively material decisions, including here any decision to seek additional capital by emission of additional shares. Not only the

17. For an explanation of this structure, see Vagts, "The European System," 27 Bus. Law. 165 (Special Issue, Feb. 1972); see also Vagts, "Reforming the "Modern" Corporation: Perspectives from the German," 80 Harv. L. Rev. 23 (1960). For a brief critical review of the actual separation of the two organs, see Roth "Supervision of Corporate Management: The Outside Director and the German Experience," $51 \mathrm{~N}$. Car. L. Rev. 1369, 1378 (1973).

18. Cf. Wiedemann, supra n. 6 at $345-463$.

19. Thus, compare the Decision of BGH, 16 Feb., 1976 ["Audi Union"], reprinted in $21 A G 218$ (1976) (and criticized by, inter alia, Westermann, "Zum Verhalten des Grossaktionars bei Umtauschangeboten gemass \& 305 AktG," id. at 309 and Lutter, "Comment," id. at 561 (1976); see also, more generally, Lutter, "Zur Treuepflicht des Grossaktionars," id. at 225) with the Decision of BGH, 5 June, 1975 ["ITT"], 65 Bundesgerichtshof Zeitschrift 15 (1975) [BGHZ] (discussed in Rehbinder, "Treuepflichten im GmbH-Konzern," 5 ZGR 386 (1976)). But cf. OLG Saarbracken, 12 July 1979 , in $25 A G 26$ (1980). 
protection of the preemptive right led to this step but, somewhat surprisingly, the perceived need to protect against the increased likelihood that with wider share distribution a "danger" of (secondary) transfers to strangers might arise. ${ }^{20}$

The basic arguments will sound familiar to American readers, and indeed in substantial part are at least by indirection traceable to the American discussion:21

When a corporation transfers material parts of its assets to a subsidiary, this structural change thereby weakens the legal position of its shareholders, even if all shares of the subsidiary remain in the hands of the parent corporation. . . Important decisions are in this fashion transferred along with the transferred assets from the parent to the subsidiary.... [Unless prevented] such a transfer of enterprise assets would be an all too simple way for management to sidetrack the statutorily protected right of the shareholders to participation in certain important affairs. Here the corporation code does reveal a gap which should be closed by reliance upon its systematic structure and its values. ${ }^{22}$

The specifled item of concern to the court, of course, is one within the fiduciary arena, both in its conflict of interests and prudence segments: the denial of preemptive or quasi-preemptive rights otherwise owed to shareholders through the device of putting the enterprise for which that capital transaction is to be carried out in a separate subsidiary. As a transaction it bears a resemblance to the well-known Delaware case of Schreiber $v . B r y a n,{ }^{23}$ in which the parent company of a partly-owned subsidiary organized a separate subsidiary of different mixed (parent and outside) ownership to carry on a new business activity instead of raising the necessary capital from among the first subsidiary's owners. The Delaware court, following general American procedure, took the direct approach of testing the decision against received fiduciary principles or prudence and loyalty (and, on the facts, found against the plaintiff); certainly it perceived no preliminary problems concerning standing or concerning the theory of the complaint. ${ }^{24}$

The German court, which for already mentioned "direct relation" reasons would face difflculties handling the matter as an abuse

20. This focus - the "alienation", literally, of German enterprise-has been part of the German thinking on ownership issues for some time; see Lutter \& Schneider, "Die Beteiligung von Auslandern an inlandischen Aktiengesellschaften," 4 ZGR 182 (1975).

21. See particularly Timm, supra $n .14$ at 173 ; and more generally Wiedemann, supra n. 6 at $347-53$ (both cited in the decision).

22. $37 \mathrm{JZ}$ at 606 (my translation).

23. 396 A.2d 512 (Del. Ch. 1978). On the enabling question per se, see infra $n .26$ and accompanying text.

24. See generally Jennings \& Buxbaum, supra n. 9 at $497-99,506-509$. 
of fiduciary power, let along as a duty of care problem, ${ }^{25}$ successfully resolved it as an enabling power issue. Indeed, in so doing it may have stated a stronger rule for complaining shareholder, since neither imprudent waste of assets nor self-dealing would be the limiting conditions of the action. Not the motive for the failure of the board of directors of the parent company to submit a decision to its shareholders would be the issue, but simply the fact of failing to do so. ${ }^{26}$ By contrast, American law as presently developed would have to look to the motive for that failure, finding it in either imprudence or disloyalty; motives which may well exist in some cases of partial spin-offs but equally well might not exist in others and in any event would have nothing to do with the underlying structural question of a proper division of competence between owners and managers.

It is interesting to compare the court's approach with Professor Eisenberg's model of this appropriate division of competence. ${ }^{27}$ His basic argument concerning the right of shareholders to participate in a decision to sell a substantial part, though less than substantially all of the corporate assets, rests on an historical demonstration that modern statutes mandating shareholder participation in the latter case were designed to change the common law rule requiring unanimous approval of such a transaction but were not designed "to dispense with requirements of shareholder approval otherwise imposed by law."28 As to other transactions involving the assets of a wholly owned subsidiary which itself, however, holds only a substantial part but not substantially all of the corporate parent's assets, Eisenberg provides essentially a "pass-through" analysis. ${ }^{29}$ For example, a merger by which the subsidiary becomes the survivor should be treated, for shareholder voting purposes, as if it had been a merger by which the parent became that survivor; if a sufficient proportion of parent company stock would have been issued to require shareholder approval under statutory merger enabling provisions, the (actual) transaction by the subsidiary also should require parent shareholder approval. As to transactions not involving the corporation's assets, Eisenberg reverts to analogous solutions; that is most

25. To the extent that the affliate enterprise structure of Pennzoil would qualify as a Konzern under German law, however, the direct actio pro societate of Part III of the Aktg, supra n.3, second paragraph, would be available to outside shareholders of the subsidiary. In Maller, of course, there were no such persons by definition in the $100 \%$ subsidiary.

26. The court also, however, extended the pass-through concept to hypothetical situations in which the subsidiary's additional capital needs were supplied wholly by the parent, a transaction which does not raise the flduciary problem of loyalty (though it could raise an issue of prudence); cf. Rehbinder, supra n. 4 at 102. This comes closer to a pure enabling and division of powers question than does the case of a capital increase supplied by outsiders. The American analogy would be the wellknown case of Eisenberg v. Flying Tiger Lines, Inc., 451 F.2d 267 (2d Cir. 1971) which, however, turns on the issue whether the suit is a direct or a derivative one; compare supra n. 11-13 and accompanying text.

27. Eisenberg, The Structure of the Corporation Ch. 18 (1976).

28. Id. at 261.

29. Id. at $303 \mathrm{ff}$. 
obvious when the issue involves the election of the directors of the subsidiary corporation. ${ }^{30}$

The Muller decision in essence operationalizes that approach. It is only a first step, of course, since the issue was posed as one involving the initial transfer of the parent's dock and warehouse facilities to the limited partnership of which its wholly owned subsidiary was both the general partner and (in fact) limited partner, even if it was the specter of later transactions in the new setting that animated the court. By questioning this initial transfer in the absence of more explicit shareholder consent, however, the opinion at least achieves for the parent's shareholders the opportunity of structuring their later involvement in later decisions by the subsidiary concerning those major assets. ${ }^{31}$ Whether it is preferable to enjoin the initial step and thus in essence to provide shareholders the right already then to discuss and fashion the process by which the actual later transactions involving those transferred assets are to be taken, or preferable already at the outset for the courts to fashion the specific mandatory legal regimes predictably needed for that later set of potential dispositive decisions is not easy to resolve. ${ }^{32}$ Given the present unsatisfactory situation under the American law already criticized by Eisenberg, however, it is at the least clear that Muller is a significant improvement on that present situation, one which might well be used as a guide to American courts in the development of this aspect of corporate governance.

30. Id. at $299 \mathrm{ff}, 306$.

31. The decision also creates such a regime directly. It requires the vote of the shareholders on any increase in the capitalization of the subsidiary partnership.

32. Cf. Rehbinder, supra n. 4 at 99. 